\title{
男性腎移植患者における性機能の研究
}

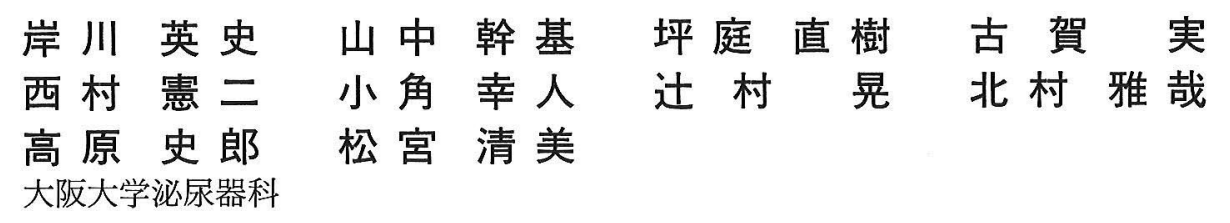

key words：腎移植，男性性機能，アンケート，内分泌

〈要旨〉

慢性腎不全患者に高率に起こるといわれている男性性機能障害の腎移植による変化を調べるため, 当科にて施行 した男性腎移植患者に対し，性機能に関するアンケート調査を行い，57 例の回答を得た，うち 42 例で血中 luteinizing hormone (LH), follicle-stimulating hormone (FSH), prolactin (PRL), testosterone (T), free T 值を測定した. 性交頻度は血液透析時, 腎移植後ともに低く, 全体としては腎移植にて顕著な増加は認めなかったが, 透析療法中 に性機能障害のため性交不能であった 9 例のうち 6 例が腎移植後性交可能となったが，これらの症例の腎移植時年 齢はいずれも 40 歳以下であった. 勃起能, 射精状態を含めた性機能では 11 例で腎移植後改善を認めた。性機能の 改善群と非改善群で血清クレアチニン値, 免疫抑制法, 透析期間, 血中ホルモン值等について検討したが, 有意差 は認めなかった．血中ホルモン值は移植後ほぼ正常值に復していた，以上より慢性腎不全患者における性機能障害 の要因は内分泌系以外に加齢により不可逆的になる血管系, 神経系などの変化が考えられ, 性機能の回復には早期 の腎移植が望ましいものと思われた.

\section{Sexual function in male kidney transplants}

Hidefumi Kishikawa, Masaki Yamanaka, Naoki Tsuboniwa, Minoru Koga, Kenji Nishimura, Yukito Kokado, Akira Tsujimura, Masaya Kitamura, Shirou Takahara, Kiyomi Matsumiya

Department of Urology, Osaka University Medical School

To evaluate improvement in sexual functions after renal transplantation, we conducted a questionarre survey regarding this issue. Fifty-seven patients who had undergone renal transplantation in our hospital were evaluated. Hormonal profiles ( $\mathrm{LH}, \mathrm{FSH}, \mathrm{PRL}, \mathrm{T}$, free $\mathrm{T}$ ) of 42 patients were also analyzed after informed consent was obtained.

Frequency of coitus was lower among hemodialysis patients compared with that among normal control and there was no significant improvement observed after renal transplantation, although hormonal profiles of renal transplants became very similar to those of normal control. (LH : $6.2 \pm 3.8 \mathrm{mlU} / \mathrm{ml}$, FSH : $9.9 \pm 6.6 \mathrm{mlU} / \mathrm{ml}$, $\mathrm{PRL}: 5.9 \pm 2.9 \mathrm{ng} / \mathrm{m} l, \mathrm{~T}: 390 \pm 110 \mathrm{ng} / \mathrm{d} l$, free $\mathrm{T}: 16.5 \pm 5.3 \mathrm{pg} / \mathrm{m} l)$. Serum creatinine, immunosuppressants, duration of hemodialysis and hormonal profile were evaluated between two patients groups with or without improvement of sexual function after renal transplantation, but there was no significant difference observed. Of 9 impotent cases, 6 patients who had undergone transplantation before 40 years of age, became potent after renal transplantation.

Factors other than hormones might be important for sexual functions of patients receiving hemodialysis and the importance of transplantation at a younger age is suggested.

北村 雅哉 大阪大学泌尿器科 † 565-0871 吹田市山田丘 2-2 (06-879-3531)

Masaya Kitamura Fax 06-879-3539

〔受付: 平成 9 年 11 月 5 日, 受理 : 平成 10 年 6 月 16 日〕 
緒言

近年の透析療法の進歩により慢性腎不全患者におろ ても長期的生命予後が期待可能となり, 社会復帰も実 現されるようになってきた。しかし，今なお患者を悩 ませている問題に性機能の低下が挙げられる。慢性腎 不全患者では高率に男性性機能障害が起こるといわれ ており，その原因および治療法は未だ確立されていな い. また，対症療法である血液透析では改善が期待で きないとされている。一方, 慢性腎不全の根治療法で ある腎移植にて男性性機能障害に改善が認められたと いう報告も散見される。つまり腎移植によって男性性 機能障害がどの程度改善するのか，また血液透析患者 との相違点を検討することは，慢性腎不全患者におけ る男性性機能障害の原因究明および治療の手掛りにな ると思われる。そこで今回, 男性腎移植患者の性機能 をアンケート調査し, 血中ホルモン值との関係を検討 した.

\section{I．対象および方法}

対象は 1965 年 3 月から 1996 年 6 月までに大阪大学 泌尿器科にて腎移植を施行後, 1997 年 10 月現在, 移植 腎生着中の男性患者 156 名中アンケートに対して回答 を得た 57 例である (回答率 $36.5 \%$ )。年齢は 21〜 68 歳 (平均 $45.1 \pm 9.2$ 歳), 腎移植時年齢は $12 \sim 60$ 歳 (平均 $37.0 \pm 9.2$ 歳)，透析期間は 0 ～179 分月（平均 43.9土 45.9 加), 腎移植後経過期間は 4 271 か月 (平均 $93.0 \pm 57.8$ か月) であった。また現在の血清クレアチ ニン値は平均 $1.69 \pm 1.03 \mathrm{mg} / \mathrm{d} l$, 血中へモグロビン濃 度は平均 $13.1 \pm 2.0 \mathrm{~g} / \mathrm{d} l$ であった，原疾患として糖尿 病や神経変性疾患など直接性機能障害をきたしうる疾 患を持つ症例はなく，全例血液透析にて維持されてい た．移植腎動脈は原則として右もしくは左の内腸骨動 脈と端々吻合した，免疫抑制法は conventional（アザ チオプリン，ステロイド） 5 例，サイクロスポリン 47 例，タクロリムス 5 例であった。また，腎移植後糖尿 病は 11 例に発症したものの，いずれも軽度で 10 例は 食事療法のみにて血糖コントロールされていた。

アンケートは腎移植前（透析療法中）および現在の 性交頻度, 腎移植前後に扝ける勃起能, 射精状態の変 化について質問し，表 1 のごとく番号で回答を得た． 性交頻度に関してはパートナーのいない症例は対象よ り除外した，勃起能，射精状態，性機能（総合的満足 度)に関しては 1 を改善, 2 を不変, 3 以上を悪化とし,
表 1 アンケート回答例

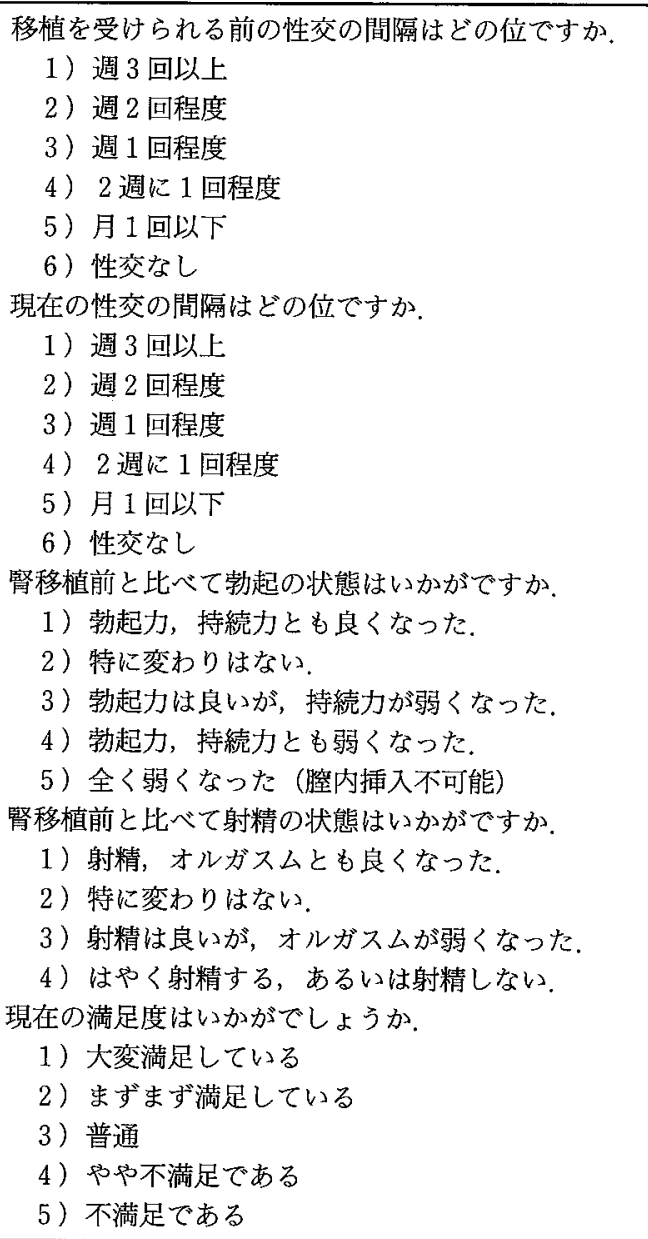

また各々の差の合計点が 5 以上の症例を改善あり，4 以下の症例を改善なしとした，さらに，協力の得られ た 42 例（平均年歯 $44.8 \pm 9.3$ 歳）で，血中 LH, FSH, PRL, T, free T 值を RIA 法にて測定した.

\section{II. 結 果}

\section{1.アンケート調查の結果}

1）性交頻度

図 1 は対象患者の腎移植前（血液透析中）および現 在の性交頻度を年代別に図示したものである．熊本ら の報告 ${ }^{1)}$ と比較すると腎移植前後とも各年代において 性交頻度は健康男性より減少して扔り，なかでも腎移 植前に性交渉のない症例が 20 歳代で $27 \% ， 30$ 歳代で 16\%，40 歳代で $17 \%$ と目立っておうり，これら 12 例中 9 例では性機能障害のため性交不能であった，腎移植 後においても全体的に大きな変化はないものの，性交 不能であった 9 例中 6 例で性交可能となった，この 6 例の腎移植時年齢はいずれも 40 歳未満であり, 逆に残 り 3 例は 40 歳以上で腎移植を施行した症例であった。 


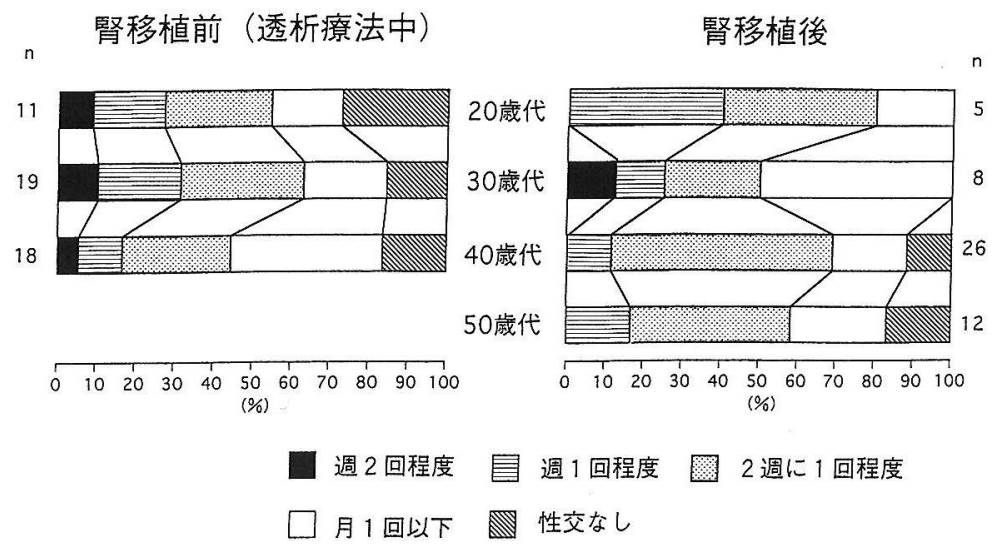

図 1 腎移植前後における性交頻度
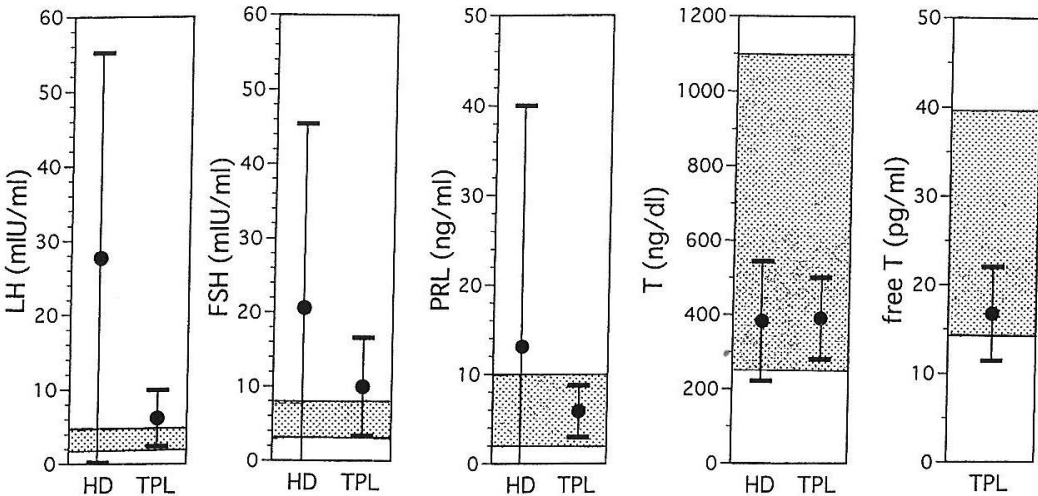

図 2 透析患者群 (HD) と移植患者群 (TPL) の血中ホルモン值

部分は正常值を示す。

2 ) 勃起能, 射精状態, 総合的性機能

表 2 は腎移植前後における勃起能, 射精状態および 性機能の変化である，勃起能，射精状態ともに改善例 がみられる一方，悪化例も同程度存在し，総合的に性 機能に関する満足度の改善のみられた症例は全体の 2 割に満たなかった。その改善率を腎移植時年代別にみ

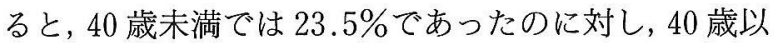
上では $13.0 \%$ とらに低率であった，その他，腎移植 後の性機能変化に影響を与えうる因子として血清クレ アチニン値, へモグロビン濃度, 透析期間（以上 $t$ 検 定)，免疫抑制法，腎移植後の糖尿病(以上力イ 2 垂検 定）につき検討したが，いずれも有意差を認めなかっ た。

\section{2. 内分泌学的検討}

透析患者 ${ }^{2)}$ 腎移植患者における血中ホルモン值を 図 2 に示す，腎移植患者においてはLH, FSH ともに 約半数の症例で正常上限值を超えるものの，その程度 は軽度であり全体としては，僅かに上昇しているだけ で, PRL は殆どの症例が正常範囲内にあり, T, free T はともに正常からやや低值であり平均值は正常範囲内
表 2 腎移植前後における性機能 変化

\begin{tabular}{|c|c|c|}
\hline \multicolumn{3}{|l|}{ （勃起能） } \\
\hline & 改善 & : 15 例 $(26.3 \%)$ \\
\hline & 不変 & : 31 例 $(54.4 \%)$ \\
\hline & 悪化 & : 11 例 $(19.3 \%)$ \\
\hline \multicolumn{3}{|c|}{ （射精状態） } \\
\hline & 改善 & : 7 例 $(12.3 \%)$ \\
\hline & 不変 & : 35 例 $(61.4 \%)$ \\
\hline & 悪化 & : 15 例 $(26.3 \%)$ \\
\hline \multicolumn{3}{|l|}{ （性機能） } \\
\hline & \multicolumn{2}{|c|}{ 改善あり：11例（19.3\%） } \\
\hline & \multicolumn{2}{|c|}{ 改善なし：46 例（80.7\%） } \\
\hline
\end{tabular}

であった，つまり，透析患者に見られた内分泌学的異 常は移植患者においてはほとんどの症例で改善されて いた。しかし，性機能に改善のみられた群と改善のみ られなかった群の間では，血中ホルモン值に有意差を 認めなかった．また，各々のホルモンについて異常值 をとる症例における勃起能および射精状態をみても， 腎移植患者全体との差を認めなかった。

図 3 は腎移植後における血中ホルモン値の経時的推 移である，LH，FSH とも術後 100 か月までは高值を 

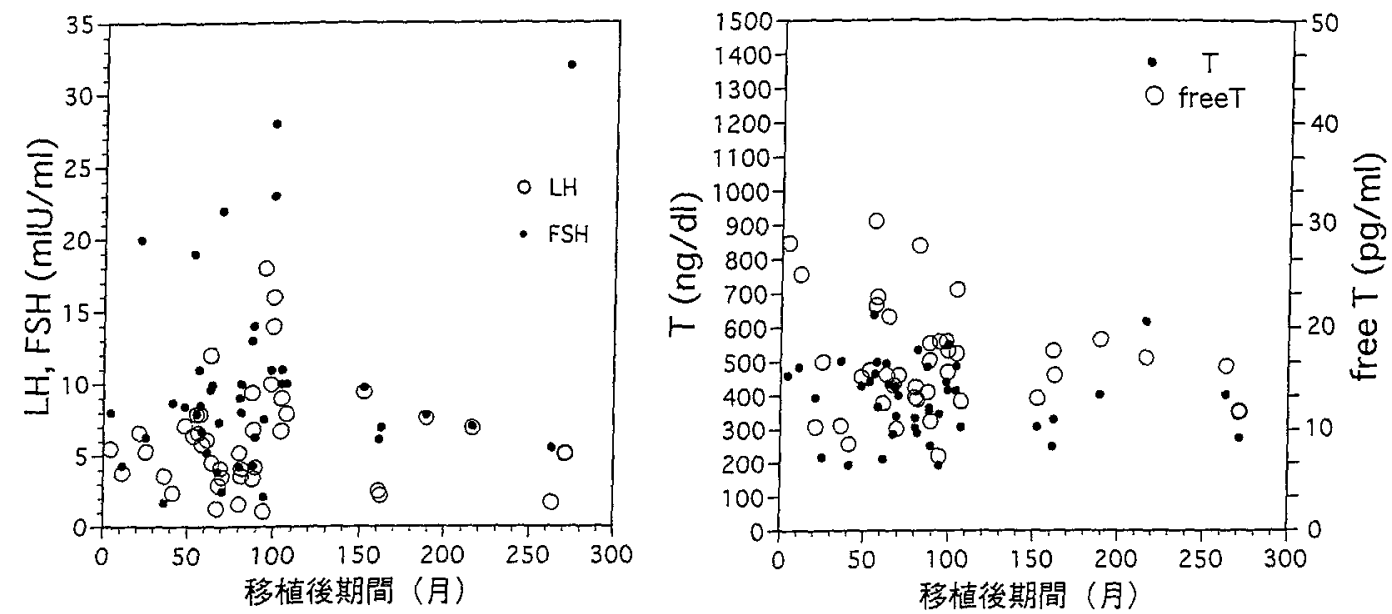

図 3 腎移植後期間と血中 LH, FSH, T, free T 值

とる症例もみられるが多くは術後早期より正常上限に 近い值をとり，また長期的には漸減していった。 $T$, free $\mathrm{T}$ は術後早期より, 長期間正常加ら正常下限値付 近を推移していた。

\section{III. 考 察}

慢性腎不全患者では高率に男性性機能障害を起こす とされており，その割合は, Abram ら ${ }^{3)}$ や, Menchini-

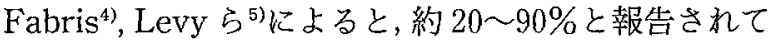
いる。本邦においても赤枝ら ${ }^{6}$ が，80\%に性欲低下を， $75 \% に$ 勃起能低下をきたしたとしている。この腎不全 後の性機能低下は血液透析療法では改善しないことが 知られている7) 一方, 腎不全の根治療法である腎移植 によって改善が得られたとする報告が散見される8). そこで当科にて施行した男性腎移植患者における性機 能を検討することを目的としてアンケート調査を行っ た.

先ず性交頻度であるが熊本らの報告 ${ }^{1)}$ にる健康男 性と比較すると，腎移植前ではかなり減少しており性 欲減退拉よび勃起能低下がうかがわれる，中でも性交 涉のない症例の多さが目立った。腎移植後も，全体と してみると勃起能，射精状態については少なくとも自 賞的には有意な改善は認められなかったが，透析療法 中に性機能障害のため性交不能であった 9 症例のうち 6 例では術後性交可能となった。これらの症例はいず れも 40 歳末満で腎移植を受けており, 若年時に移植を 行うことによって性機能が改善する可能性が示唆され た.

次に内分泌系であるが，一般に慢性腎不全患者では LH, FSH, PRL は異常高值を，Tは低值をとりやすい ことが知られている，今回の腎移植患者における血中
ホルモン値の結果では正常基準值との大きな差はな

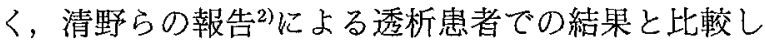
ても LH, FSH, PRL は顕著に改善したと思われ，これ は諸家の報告 ${ }^{10,11)}$ とも一致する。 また $\mathrm{T}$, free Tも活添 正常範囲内にあった，つまり少なくとも視床下部一下 垂体系の内分泌異常は可逆的で, 腎移植により改善さ れることが確認されたといえる。

腎不全患者における性機能障害の原因としては極度 の責血や原疾患としての糖尿病などを除くと未だ解明 されておらず，血管系の障害 ${ }^{12)}$, 神経系障害 ${ }^{13)}$, 内分泌 異常 ${ }^{14,15)}$, 精神的要因 ${ }^{5)}$, 低亜鉛血症 ${ }^{16)}$, ビタミン $\mathrm{B}_{12}$ 欠 乏17などの関与が考えられている。一方, 腎移植後にも 勃起能低下が起こりうるという報告もあり ${ }^{18)}$ ，原因と して血流低下，免没抑制剤や降圧剤等の薬剤の関与な どがあげられている。

今回の調查において腎移植患者では，内分泌系の正 常化が認められたにもかかわらず，自覚的性機能改善 は顕著でなかった点から考えると, 慢性腎不全患者に おける性機能障害の主因は内分泌系以外にあることが 示唆された．さらに透析患者の性機能障害は加齢とと もに高率になるという報告 ${ }^{19)}$ があり，また今回の調査 においても若年時に腎移植を受けた患者に性機能の改 善が認められたことなどから，動脈硬化や神経変性な ぞ年齢とともに不可逆的になる変化が性機能障害の要 因となっている可能性があり，性機能の回復には早期 の腎移植が望ましいものと思われた。

\section{文献}

1）熊本悦明，青木正治，毛利和富：加跲による男子性機 能の変化．ホルモンと臨床 $34 ： 239-246,1986$

2）清野耕治, 久保 隆, 長根 裕, 細川久昭：男性透析 患者の性機能について. 臨牀透析 10：1531-1538, 1994 
3) Abram HS, Hester LR, Sheridan WM : Sexual dysfunction in patient with chronic renal failure. J Nerv Ment Dis 160:220-226, 1975

4) Menchini-Fabris GF, Tuchi $P$, Giorgi $P$, Canale $D$ : Diagnosis and treatment of sexual dysfunction in patients affected by chronic renal failure on hemodialysis. Contrib Nephrol 77 :24-33, 1990

5) Levy NB: Sexual adjustment to maintenance hemodialysis and renal transplantation. Trans Am Soc Artif Int Organs $19: 138-143,1973$

6）赤枝輝明：慢性腎不全患者におけるインポテンスに関 する研究. 日泌尿会誌 $73: 189-205,1982$

7) Larsen NA : Sexual problems of patients on RDT and after renal transplantation. Proc Eur Dial Transplant Assoc $9: 271-277,1972$

8) Salvatierra O, Fortmann JL, Belzer FO : Sexual function in males before and after renal transplantation. Urology $5: 64-66,1975$

9) Holdsworth SR, de Kretser DM, Atkins RC:A comparison of hemodialysis and transplantation in reversing the uremic disturbance of male reproductive function. Clin Nephrol 10:146-150, 1978

10) Koutsikos D, Sarandakou A, Agroyannis B, Tzanatos H, Tserkezis G, Kapetanaki A, Founta P, Phocas I: Hormonal profiles in successful renal transplant male recipients. Transplant Proc 22 : 1399-1404, 1990

11) Chopp RT, Mendez R : Sexual function and hormonal abnormalities in uremic men on chronic dialysis and after renal transplantation. Fertil Steril $29: 661-666,1978$

12) Kaufman JM, Hatzichristou DG, Mulhall JP, Fitch WP, Goldstein I : Impotence and chronic renal failure. J Urol 151 : 612-618, 1994

13) Campese VM, Procci WR, Levitan D, Romoff MS : Autonomic nervous system dysfunction and impotence in uremia. Am J Nephrol $2: 140-143,1982$

14) Davidson JM, Camargo CA, Smith ER : Effects of androgen on sexual behavior in hypogonadal men. J Clin Endocrinol Metab 48 : 955-958, 1979

15) Bommer J, Retz E, Pozo E, Bommer G: Improved sexual function in male hemodialysis patients on bromocriptine. Lancet $2: 496-497,1979$

16) Antoniou LD, Shalhoub RJ, Sudhaker T, Smith JC $\mathrm{Jr}$ : Reversal of uremic impotence by zinc. Lancet $1: 895-898,1977$

17）鈴木伸和，熊本悦明，渋谷秋彦，木村 慎，佐藤嘉一， 堀田浩貴, 塚本泰司, 菅原剛太郎, 江端範名, 平田輝 夫, 千葉栄市, 丹田 均, 坂 丈敏, 山崎清仁, 大村 清隆：メコバラミン（メチル B12）は透析症例の男性 性機能を改善させ得るか. 腎と透析 $36: 1035-1040$, 1994 .

18) Nghiem DD, Corry RJ, Picon-Mendez G, Lee HM : Factors influencing male sexual impotence after renal transplantation. Urology $21: 49-52,1983$

19）鈴木伸和, 熊本悦明: 男性透析患者の性機能の研究. 日泌尿会誌 $86 ： 1088-1097,1995$ 